Article

\title{
Use of Biofuel Industry Wastes as Alternative Nutrient Sources for DHA-Yielding Schizochytrium limacinum Production
}

\author{
Sofoklis Bouras ${ }^{1}$, Nikolaos Katsoulas ${ }^{1, * \mathbb{D}}$, Dimitrios Antoniadis ${ }^{1}$ and \\ Ioannis T. Karapanagiotidis ${ }^{2}$ D \\ 1 Laboratory of Agricultural Constructions and Environmental Control, Department of Agriculture Crop \\ Production and Rural Environment, University of Thessaly, Fytokou Street, 38446 Volos, Greece; \\ bourassofoklis@gmail.com (S.B.); dgantoniadis@gmail.com (D.A.) \\ 2 Aquaculture Laboratory, Department of Ichthyology and Aquatic Environment, University of Thessaly, \\ Fytokou Street, 38446 Volos, Greece; ikarapan@uth.gr \\ * Correspondence: nkatsoul@uth.gr; Tel.: +30-24210-93249; Fax: +30-24210-93144
}

Received: 15 May 2020; Accepted: 24 June 2020; Published: 26 June 2020

check for updates

\begin{abstract}
The simultaneous use of crude glycerol and effluent from anaerobic digestate, both wastes derived from the biofuel industry, were tested in the frame of circular economy concept, as potential low-cost nutrient sources for the cultivation of rich in docosahexaenoic acid (DHA) oil microalgae strain Schizochytrium limacinum SR21. Initially, the optimal carbon and nitrogen concentration levels for high S. limacinum biomass and lipids production were determined, in a culture media containing conventional, high cost, organic nitrogen sources (yeast extract and peptone), micronutrients and crude glycerol at varying concentrations. Then, the effect of a culture media composed of crude glycerol (as carbon source) and effluent digestate at varying proportions on biomass productivity, lipid accumulation, proximate composition, carbon assimilation and fatty acid content were determined. It was shown that the biomass and total lipid content increased considerably with varying effluent concentrations reaching $49.2 \mathrm{~g} \mathrm{~L}^{-1}$ at $48 \%(v / v)$ of effluent concentration, while the lipid yield at the same effluent concentration reached $10.15 \mathrm{~g} \mathrm{~L}^{-1}$, compared to $17.0 \mathrm{~g} \mathrm{~L}^{-1}$ dry biomass and $10.2 \mathrm{~g} \mathrm{~L}^{-1}$ lipid yield when yeast extract and peptone medium with micronutrients was used. Compared to the control treatment, the above production was obtained with $48 \%$ less inorganic salts, which are needed for the preparation of the artificial sea water. It was shown that Schizochytrium limacinum SR21 was able to remediate $40 \%$ of the total organic carbon content of the biofuel wastes, while DHA productivity remained at low levels with saturated fatty acids comprising the main fraction of total fatty acid content. The results of the present study suggest that the simultaneous use of two waste streams from the biofuel industry can serve as potential nutrient sources for the growth of Schizochytrium limacinum SR21, replacing the high cost organic nutrients and up to one half the required artificial sea water salts, but upregulation of DHA productivity through optimization of the abiotic environment is necessary for industrial application, including aqua feed production.
\end{abstract}

Keywords: microalgae; biofuel waste management; biodiesel; biogas; digestate; phycoremidiation; digestate; docosahexaenoic acid (DHA); aquaculture

\section{Introduction}

The concept of circular economy (CE) is an exploitative industrial model, characterized as a regenerative system with a circular flow of materials and use of raw materials and energy through multiple phases [1]. The circular model is an alternative to the linear developmental model of the 20th century, where natural resources were used without limits to manufacture products, a process 
coupled with generation of waste without proper recycling [2], which led to heavy industrialization. Based on the CE concept, environmental friendly policies have been influenced and shaped worldwide, due to the rising global concerns and ecological awareness [3]. In the frame of a circular economy, converting wastes into value added products can increase their valorization, providing alternative routes of exploitation and environmental benefits from their management.

Considering the CE concept, crude glycerol and decomposed organic matter, which are wastes produced from two distinct processes, could be used as the main input for microalgae production, which is a high value product. In more detail:

- Crude glycerol is generated during industrial scale biodiesel production by acid or alkali catalyzed transesterification of triglycerides. These include vegetable oil, animal fats and waste cooking oils $[4,5]$. The annual production within the countries of European Union was 12 million tons in 2017 [6]. For each ton of biodiesel produced, $100 \mathrm{~kg}$ of crude glycerol is generated [7]. Crude glycerol has low economic value. Its purification [8] for pharmaceutical and cosmetic applications has a significant cost [9], while its disposal can be harmful for the environment. An alternative method of crude glycerol valorization is its use as an organic carbon source for microalgae fermentation and anaerobic digestion [10]. Other methods include syngas production (gasification) [11], bio-char production (pyrolysis) [12] and bio-oil production (liquefaction) [13].

- Decomposed organic matter (or digestate) is generated during biogas production by the anaerobic microbial decomposition of crop residues from arable farming, food waste and manure livestock farming $[14,15]$. The digestate is composed primarily of biomethane $(60-70 \%)$, carbon dioxide and minor traces of ammonia hydrogen, sulfide and water vapor [16]. Nitrogen is primarily present in the form of ammonium $\left(\mathrm{NH}_{4}{ }^{+}\right)$derived from complex organic nitrogen compounds mineralization [17], whereas phosphorus in the form of organic and inorganic phosphates both contained in the liquid phase [18]. With regard to potassium, it retains its cationic form consequently being available in both liquid and solid phase [19]. Phycoremidiation is a process where the digestate is utilized as a source of nutrients in microalgae cultures [20]. Several researchers implemented this process to reduce to a substantial amount, ammonia and phosphate levels in digestates derived from different manure types [21-23]. The digestate can be also utilized in agriculture crop fertilization due to its high nutritional value, since it is rich in nitrogen, phosphorous, potassium and micronutrients. However, uncontrolled land applications can induce eutrophication due to excess nutrient leeching [20].

The biomass produced from microalgae can serve as feed stock for renewable energy in the biofuel industry (biodiesel and bioethanol) [24,25], a promising step in order to decouple the dependency of the biofuel industry from the primary production sector. Furthermore, it can be used for the production of other high value products such as antioxidants and vitamins [26], phytochemicals, food colorants [27], protein sources for farmed animals and aquaculture [28] and $n-3$ polyunsaturated fatty acids (PUFA) [29].

In relation to the microalgae production, some marine microorganisms from the family of thraustochytrids have attracted a vast interest in the scientific community during the last two decades, due to their high lipid productivity and docosahexaenoic acid (DHA) content [30]. It has to be noted that several approaches have been introduced in order to classify these heterotrophic marine microorganisms, either with a mycological or protistical orientation [31,32]. The current study will adopt the term heterotrophic microalgae, which has been used by the scientific community in previous and recent research [33-39]. The strain Schizochytrium limacinum (rearranged taxonomically to the genus Aurantiochytrium) has the ability to accumulate lipids up to $50 \%$ of its total dry weight, in a short period of time, with a DHA yield of $34 \%$ of the total lipid content [40]. These saline microorganisms are cultivated heterotrophically via aerobic fermentation in steered bioreactors in a culture media containing (a) a source of inorganic or organic carbon (glycose or pure glycerol), (b) a source of inorganic or organic nitrogen and (c) micronutrients that are necessary for their growth. 
In order to produce one ton of oil from oleaginous microorganisms, five tons of reducing sugars would be needed, considering that an ideal conversion of $100 \mathrm{~g}$ of glucose would yield $20 \mathrm{~g}$ of oil [41]. Due to the high cost of the growth medium [42] for the industrial production of DHA using Schizochytrium limacinum, several studies are focusing on the exploitation of alternative cheap carbon sources. These include liquid residues from potato chip processing [43], breadcrumbs [44], shochu distillery wastewater [45], coconut water as a medium additive [46] and sweet sorghum juice [47]. Although growth and lipid production were achieved utilizing these alternative carbon sources, biomass and DHA production were still low compared to industrial production standards. However, in another study, conventional carbon sources were substituted with maize starch hydrolysate, biomass and DHA, which yield reached $85.27 \mathrm{~g} \mathrm{~L}^{-1}$ and $20.7 \mathrm{~g} \mathrm{~L}^{-1}$, respectively [43]. With regard to crude glycerol, it has been successfully used in several culture media in order to substitute conventional and expensive carbon sources (glucose and pure glycerol). Chi et al. [9] reported a biomass production of $22.1 \mathrm{~g} \mathrm{~L}^{-1}$ and DHA yield of $4.9 \mathrm{~g} \mathrm{~L}^{-1}$. These values improved significantly when Chi et al. [48] utilized a fermentation strategy related to varying oxygen supply in relation to the developmental stages of the microorganism during the fermentation process, yielding $37.9 \mathrm{~g} \mathrm{~L}^{-1}$ dried biomass and $6.59 \mathrm{~g} \mathrm{~L}^{-1}$ DHA. These findings suggest that conventional carbon sources can be successfully substituted with several waste streams from the food processing and biofuel industry in order to cut down production cost and increase circularity.

In addition, the use of saline waste water has been investigated to reduce the use of artificial sea water [49], while different possible nitrogen sources have been tested to replace the conventional use of the much more expensive organic nitrogen sources derived from combined amounts of yeast extract and peptone $[42,50]$. Nevertheless, the combination of both waste streams from biodiesel and biogas production for the production of Schizochytrium limacinum, which is a high DHA value product, has not been extensively studied.

It has to be noted that the DHA is a critical nutrient in aqua feeds, which is currently only commercially available in high volumes in fish oil. However, aquaculture is now seeking suitable and sustainable lipid sources for aqua feeds [51] alternative to wild fish stocks [52]. In this context, microalgae have the highest potential for fish oil replacement, since they may contain higher levels of n-3 highly unsaturated fatty acids than fish oil [53-55].

Thus, the aim of this work was to assess the effects of the simultaneous use of waste streams derived from the biofuel industry, as potential low-cost ingredients of the culture media, on the growth, biomass and DHA production of Schizochytrium limacinum SR21 cultivated heterotrophically. In particular, the effects of using crude glycerol (alternative carbon source) and effluent from anaerobic digestates derived from crop and livestock farming residues enriched with inorganic nitrogen (alternative macronutrients and trace elements source) on the above production parameters will be assessed.

\section{Materials and Methods}

\subsection{Microorganism}

The strain Schizochytrium limacinum SR21 (Aurantiochytrium limacinum SR21, ATCC ${ }^{\circledR}$ MYA-1381 ${ }^{\mathrm{TM}}$ ) was obtained from the American Type Culture Collection (ATCC). Activation of cells in order to develop the inoculum was performed in a $250 \mathrm{~mL}$ Erlenmeyer flask containing $50 \mathrm{~mL}$ of growth medium, comprising $5 \mathrm{~g} \mathrm{~L}^{-1}$ glucose, $1 \mathrm{~g} \mathrm{~L}^{-1}$ peptone and $1 \mathrm{~g} \mathrm{~L}^{-1}$ yeast extract, in Artificial Sea Water (ASW). The inoculum culture was incubated for 2 days at $21^{\circ} \mathrm{C}$ on an orbital shaker set at $130 \mathrm{rpm}$. Prior to inoculation, in this and in all the following growth media, the $\mathrm{pH}$ of the medium was adjusted to 7.0 with $2 \mathrm{M} \mathrm{KOH}$ and autoclaved at $121^{\circ} \mathrm{C}$ for $15 \mathrm{~min}$. The strain was preserved in $20 \%$ glycerol $(v / v)$ at $-20^{\circ} \mathrm{C}$ according to Sun et al. [40]. 


\subsection{Preparation of Growth Media}

\subsubsection{Artificial Sea Water}

Schizochytrium limacinum SR21 is a marine heterotrophic alga; thus, the growth media are based on artificial seawater. For the preparation of the ASW, sea salts (Aquaforest sp. O.o., Brzesko, Poland) containing $30 \mathrm{~g} \mathrm{~L}^{-1} \mathrm{NaCL}, 1.2 \mathrm{~g} \mathrm{~L}^{-1} \mathrm{Mg}, 0.742 \mathrm{~g} \mathrm{~L}^{-1} \mathrm{~K}, 0.33 \mathrm{~g} \mathrm{~L}^{-1}$ Ca were mixed with distilled water.

\subsubsection{Micronutrients}

Two different experiments were carried out in the frame of this study, as analyzed in detail in Section 2.3.2. In experiment 1 , the ASW was enriched with $5 \mathrm{~mL} \mathrm{~L}^{-1}$ of micronutrients, containing: $0.001 \mathrm{~g} \mathrm{~L}^{-1} \mathrm{ZnSO}_{4} \cdot 7 \mathrm{H}_{2} \mathrm{O}, 0.002 \mathrm{~g} \mathrm{~L}^{-1} \mathrm{MnSO}_{4} \cdot 4 \mathrm{H}_{2} \mathrm{O}, 0.01 \mathrm{~g} \mathrm{~L}^{-1} \mathrm{H}_{3} \mathrm{BO}_{3}, 0.001 \mathrm{~g} \mathrm{~L}^{-1} \mathrm{Co}\left(\mathrm{NO}_{3}\right)_{2} \cdot 6 \mathrm{H}_{2} \mathrm{O}$, $0.001 \mathrm{~g} \mathrm{~L}^{-1} \mathrm{Na}_{2} \mathrm{MoO}_{4} \cdot 2 \mathrm{H}_{2} \mathrm{O}, 0.0005 \mathrm{~g} \mathrm{~L}^{-1} \mathrm{CuSO}_{4} \cdot 5 \mathrm{H}_{2} \mathrm{O}, 0.7 \mathrm{~g} \mathrm{~L}^{-1} \mathrm{FeSO}_{4} \cdot 7 \mathrm{H}_{2} \mathrm{O}$ and $0.8 \mathrm{~g} \mathrm{~L}^{-1}$ EDTA (Merck KGaA, Darmstadt, Germany). In experiment 2, the above-mentioned micronutrients were added only to the control treatment ( $0 \%$ effluent), while in all other treatments, the pre-treated effluent was investigated as a possible source of micronutrients, and thus, no micronutrients were added.

\subsubsection{Crude Glycerol}

Crude glycerol was obtained from a local biodiesel plant located in the Region of Thessaly in central Greece (Elin Biofuels S.A, Volos, Greece). Their biodiesel production is based on alkali catalyzed transesterification of animal fats and waste cooking oil. The physical characteristics provided by the company were the following: glycerol $80.4 \%(w / w)$, methanol $0.7 \%(w / w), \mathrm{pH} 1.9$, Ash $2.2(\mathrm{~m} / \mathrm{m})$, moisture $11.9(w / w)$.

\subsubsection{Biogas Effluent}

Waste effluent derived from anaerobic digestion of crop and livestock farming residues (pig manure, agriculture crop residues and olive oil mill solid residues) were collected from a biogas production facility located in the Region of Thessaly in central Greece (Seitis Bros Biogas S.A, Argyroupoli, Greece). The effluent was collected prior to undergoing pressure filtration. Undigested material and solid residues were filtered through a $2 \mathrm{~mm}$ sieve. Subsequently, the filtrate was passed through an activated carbon filtration system for $48 \mathrm{~h}$ continuously and centrifuged for $15 \mathrm{~min}$ at $5000 \times \mathrm{g} \mathrm{rpm}$ and $4{ }^{\circ} \mathrm{C}$. The pre-treated effluent was then sterilized for $12 \mathrm{~h}$ at $200^{\circ} \mathrm{C}$. Extraction of phosphates $\left(\mathrm{PO}_{4}-\mathrm{P}\right)$ from effluent was performed according to [56]. P was then determined spectrophotometrically at $882 \mathrm{~nm}$ after the development of blue color in the extracts with the ammonium molybdate-ascorbic acid technique, whereas K, Ca and Na were measured using flame photometry. Trace elements in the effluent were measured by means of inductively coupled plasma atomic emission spectrometry, whereas the organic carbon content was measured with a total organic carbon analyzer (TOC-L, Shimadzu Corp, Kyoto, Japan). The elemental composition of the pre-treated waste effluents (in $\mathrm{mg} \mathrm{L}^{-1}$ ) was: Total $\mathrm{N}$ (161), P (91), Ca (1000), Mg (260), S (330), Cu (5.6), Co (30), Zn (12), Mn (11), Fe (110). The physical characteristics were: total solids $(2.2 w / w)$, conductivity $\left(15.05 \mathrm{mS} \mathrm{cm}^{-1}\right)$, Optical density at $660 \mathrm{~nm}$ (0.7), $\mathrm{pH}(7.7)$, Ash (1 w/w), Moisture (97.8 w/w), $\operatorname{COD~}\left(1 \mathrm{~g} \mathrm{~L}^{-1}\right)$.

\subsubsection{Nitrogen Sources}

Conventional fermentation media for the cultivation of S. limacinum SR21 use organic nitrogen sources derived from combined amounts of yeast extract and peptone. Nitrogen concentration is regulated since yeast extract and peptone have a total nitrogen content of $10 \% w / w$ and $1 \%$, respectively. Yeast extract and peptone were used as nitrogen sources in the experiment 1.

In experiment 2, the high cost organic nitrogen sources were replaced by the nitrogen contained in the pre-treated effluent, enriched with low cost inorganic nitrogen derived from $\mathrm{NH}_{4} \mathrm{CL}$ in order to reach a nitrogen concentration of $3.3 \mathrm{~g} \mathrm{~L}^{-1}$, that was the optimal level estimated from experiment 1 . 


\subsection{Microalgae Cultures}

\subsubsection{Seed Culture}

Seed cultures were used to inoculate the fermentation media for the subsequent experiments. Thus, a 10\% (v/v) of initial inoculum culture was transferred to $250 \mathrm{~mL}$ Erlenmeyer flasks containing $50 \mathrm{~mL}$ of fresh seed culture medium which was prepared according to [57], comprising $50 \mathrm{~g} \mathrm{~L}^{-1}$ glucose, $2 \mathrm{~g} \mathrm{~L}^{-1}$ peptone, $5 \mathrm{~g} \mathrm{~L}^{-1}$ yeast extract in Artificial Sea Water (ASW) containing $20 \mathrm{~g} \mathrm{~L}^{-1}$ sea salts and micronutrients and supplementary minerals $1.5 \mathrm{~g} \mathrm{~L}^{-1} \mathrm{KH}_{2} \mathrm{PO}_{3}$ and $0.7 \mathrm{~g} \mathrm{~L}^{-1} \mathrm{MgSO}_{4} \cdot 7 \mathrm{H}_{2} \mathrm{O}$. The seed culture was incubated for 5 days at $25^{\circ} \mathrm{C}$ on an orbital shaker set at $150 \mathrm{rpm}$.

\subsubsection{Batch Fermentation Experiments}

Two batch fermentation experiments were carried out using different fermentation media in ASW with the same inoculum and the same conditions of abiotic environment. The experiments were carried out in $500 \mathrm{~mL}$ shake flasks (DURAN ${ }^{\circledR}$ GLS $80^{\circledR}$ Laboratory Bottle Wide Mouth) containing $400 \mathrm{~mL}$ of growing medium and $10 \%(\mathrm{v} / \mathrm{v})$ inoculum of the seed culture of the microorganism. Cultures were incubated in a growth chamber at $25^{\circ} \mathrm{C}$ for 7 days on an orbital shaker set at $120 \mathrm{rpm}$. Oxygen was sparged into the medium with compressed air at a rate of $150 \mathrm{~L} \mathrm{~h}^{-1}$. During the experiment, dissolved oxygen (DO) level was maintained at $50 \%$ of saturation by regulating the oxygen supply.

In order to determine the optimal carbon and nitrogen concentration for growth and lipid accumulation, a screening experiment (experiment 1) was carried out with increasing concentrations of crude glycerol, yeast extract and peptone in ASW. Four crude glycerol concentrations (30, 60, 90, $\left.120 \mathrm{~g} \mathrm{~L}^{-1}\right)$ and five nitrogen concentrations $\left(1.1,2.2,3.3,4.4,5.5 \mathrm{~g} \mathrm{~L}^{-1}\right)$ were tested in pair combinations. The nitrogen concentration levels derived by combining equal amounts of yeast extract $(10,20,30,40$, $\left.50 \mathrm{~g} \mathrm{~L}^{-1}\right)$ and peptone $\left(10,20,30,40,50 \mathrm{~g} \mathrm{~L}^{-1}\right)$. The experiment was carried out with the same inoculum, micronutrients and supplementary minerals at the same conditions of the abiotic environment as described in Section 2.2. According to our findings, the optimal concentration of total nitrogen and crude glycerol was $3.3 \mathrm{~g} \mathrm{~L}^{-1}$ and $120 \mathrm{~g} \mathrm{~L}^{-1}$, respectively.

Based on the findings of the screening experiment, experiment 2 was conducted at the same volume of fermentation media that contained crude glycerol (as carbon source) regulated to the optimal carbon concentration $\left(120 \mathrm{~g} \mathrm{~L}^{-1}\right)$ and pre-treated effluent at varying concentrations $(0 \%, 8 \%, 16 \%$, $32 \%, 48 \% v / v)$, replacing partially the relative volume of ASW. Nitrogen was also set to the optimal concentration $\left(3.3 \mathrm{~g} \mathrm{~L}^{-1}\right)$ derived from experiment 1 , with the addition of ammonium chloride $\left(\mathrm{NH}_{4} \mathrm{Cl}\right)$ at the quantities needed considering the nitrogen levels in the pre-treated effluent and the relevant quantity of the effluent added. Phosphorus, potassium and magnesium concentrations were regulated for comparison reasons to the concentration equal to that of the experiment 1 , with the addition of $\mathrm{KH}_{2} \mathrm{PO}_{3}$ and $\mathrm{MgSO}_{4} \cdot 7 \mathrm{H}_{2} \mathrm{O}$, while micronutrients were added only to the control treatment and not to the media containing the effluent. Thus, the composition of the control fermentation medium (0\% effluent) was $120 \mathrm{~g} \mathrm{~L}^{-1}$ crude glycerol, $12.5 \mathrm{~g} \mathrm{~L}^{-1} \mathrm{NH}_{4} \mathrm{Cl}, 1.5 \mathrm{~g} \mathrm{~L}^{-1} \mathrm{KH}_{2} \mathrm{PO}_{3}, 0.7 \mathrm{~g} \mathrm{~L}^{-1} \mathrm{MgSO}_{4} \cdot 7 \mathrm{H}_{2} \mathrm{O}$ and micronutrients. The rest of the treatments $\left(8 \%, 16 \%, 32 \%, 48 \% v / v\right.$ effluent) contained $120 \mathrm{~g} \mathrm{~L}^{-1}$ crude glycerol, $3.3 \mathrm{~g} \mathrm{~L}^{-1}$ nitrogen, $\mathrm{P}, \mathrm{K}, 8 \%, 16 \%, 32 \%, 48 \%$ v $/ v$ effluent and $92 \%, 84 \%, 68 \%$ and $52 \%$ $v / v$ ASW, respectively. Furthermore, the carbon assimilation, the fatty acid content and the proximate composition of the biomass for each treatment were also determined, as described below.

\subsection{Measurements}

\subsubsection{Biomass Determination}

Biomass productivity was determined by dry weight. Cell suspensions of $400 \mathrm{~mL}$, were harvested via centrifugation at $5000 \times \mathrm{g}$ rpm for $15 \mathrm{~min}$ at $4{ }^{\circ} \mathrm{C}$. The pellet was washed twice with deionized water, flash frozen with liquid nitrogen and stored at $-80^{\circ} \mathrm{C}$. Consequently, the frozen sample was lyophilized and the cell dry weight was determined gravimetrically. 


\subsubsection{Total Lipids Extraction}

Total lipids were analyzed according to Folch et al. [58]. Chloroform: Methanol (C:M 2:1/v/v) was added to $500 \mathrm{mg}$ lyophilized sample which was previously grinded for one minute using a pestle and mortar. The solution was homogenized for 5 min using a vortex shaker (MS 3 basic, ika) and kept on ice for $3 \mathrm{~h}$. Phase separation was induced with addition of $6 \mathrm{~mL}$ of an aqueous salt solution $(0.88 \% \mathrm{KCL}$ $v / v)$. After removing the upper methanol layer from the biphasic system, the lower chloroform layer containing the lipids was filtered through a paper filter (Whatman qualitative filter paper, No 2) into $25 \mathrm{~mL}$ pre weighted test tubes. Prior filtration, funnels, filters and test tubes where prewashed with Chloroform/Methanol (C:M 2:1/v/v) solution. Solvents where evaporated with a stream of nitrogen until dryness (VLM, EVA 1 VIS, Bielefeld, Germany), and consecutively, total lipid content was determined gravimetrically. Extracted lipids were stored in C:M (2:1, v/v) at a final concentration of $20 \mathrm{mg}$ lipid/mL at $-80{ }^{\circ} \mathrm{C}$. Solvents contained $0.05 \%(w / v)$ butylated hydroxyl-toluene (BHT) as an antioxidant agent.

\subsubsection{Fatty Acid Determination}

Fatty acid methyl esters (FAME) were prepared by acid catalyzed transesterification according to Christie and Han [59]. Extracted lipid sample containing $1 \mathrm{mg}$ of total lipids and $0.1 \mathrm{mg}$ heptadecanoic acid (17:0) (Sigma Chemical Company, St. Louis, MO, USA) as internal standard was evaporated under a stream of nitrogen until dryness. Consecutively $2 \mathrm{~mL}$ of methylating agent was added containing sulfuric acid in methanol $\left(1 \% \mathrm{H}_{2} \mathrm{SO}_{4}\right.$ in methanol) and $1 \mathrm{~mL}$ of toluene. Vials were flashed with nitrogen and dry incubated on a hot block (SC154-240, Environmental Express, SC, USA) at $50{ }^{\circ} \mathrm{C}$ for $16 \mathrm{~h}$.

Crude FAMEs were purified by thin layer chromatography (TLC) on $20 \times 20 \mathrm{~cm}$ glass plate pre-coated with silica gel G (Merc silica gel 60), developed in a isohexane: diethyl ether: acetic acid $(90: 10: 1, v / v)$ solution and visualized with a $1 \%(w / v)$ iodine in $\mathrm{CH}_{3} \mathrm{Cl}_{3}$ solution. After scraping silica gel containing FAME's, they were removed by elution with an isohexane: diethyl ether $(1: 1, v / v)$ solution and re-dissolved in isohexane containing $0.05 \%$ BHT in order to prevent oxidation. Vials containing the samples were flashed with nitrogen prior storage at $-80^{\circ} \mathrm{C}$.

Separation and quantification of FAMEs was conducted by gas-liquid chromatography with a Perkin Elmer Clarus 680 coupled with a Col-Elite FAME Wax capillary column $(30 \mathrm{~m} \times 0.25 \mathrm{~mm}$ id, film thickness $0.25 \mu \mathrm{m}$ ) (PN N9316694, Perkin Elmer, Waltham, MA, USA). Hydrogen was the carrier gas with at constant flow rate of $1 \mathrm{~mL} \mathrm{~min}^{-1}$. Injector temperature was set at $240{ }^{\circ} \mathrm{C}$ with a split ratio of 1:10 at a total flow rate of $5 \mathrm{~mL} \mathrm{~min}{ }^{-1}$. The column oven was programmed from $60^{\circ} \mathrm{C}$ to $190{ }^{\circ} \mathrm{C}$ for $5 \mathrm{~min}$ at a rate of $20^{\circ} \mathrm{C} \mathrm{min}-1$ and from $190{ }^{\circ} \mathrm{C}$ to $240{ }^{\circ} \mathrm{C}$ at a rate of $5^{\circ} \mathrm{C} \mathrm{min}^{-1}$. The final temperature was maintained for $20 \mathrm{~min}$.

Identification of individual $\mathrm{FAME}_{\mathrm{S}}$ were conducted by comparison to known standards (CL40.13093, FAME MIX 37, Sigma-Aldrich, St. Louis, MO, USA). Peak areas were quantified with reference to the peak area of 17:0 as an internal standard and chromatograms were analyzed using total chrome software.

\subsubsection{Proximate Composition}

The crude protein content was determined with Kjeldahl analyses. Ash content was measured by dry ashing the samples at $600{ }^{\circ} \mathrm{C}$ for $5 \mathrm{~h}$ in a muffle furnace (Nabertherm L9/12/C6, Lilienthal, Germany). Calorific value was quantified with an IKA calorimeter (C5000, IKA Werke, Staufen, Germany). Crude carbohydrate content was quantified by subtracting the sum of the percentages of crude protein, total lipid, moisture and ash from 100.

\subsection{Statistical Analysis}

The experiment was carried out with totally randomized design, with four different substitution treatments, one control treatment and three repetitions per treatment. Mean differences between 
treatments were assessed by one-way ANOVAs, to examine interaction between pre-treated effluent, biomass productivity, crude proteins, total lipids, ash content, crude carbohydrates and calories. The difference between each group was tested using the least significant difference (LSD) from the (Turkey-HSD) test. Prior to the ANOVA, the homogeneity of the variances and the normality of the residues were tested using the Fligner-Killeen test and Shapiro-Wilk test, respectively. In all statistical tests the level of significance was set at $p=0.05$. Experimental error was quantified according to standard deviation. Data were analyzed with $\mathrm{R}$ software for statistical analysis (R Foundation for Statistical).

\section{Results}

\subsection{Biomass Productivity}

The use of pre-treated effluent enriched with inorganic nitrogen had a pronounced effect on biomass productivity of S. limacinum. As shown in Figure 1, all concentrations within the range of $8-48 \%$ $(v / v)$ promoted growth without the addition of micronutrients. When yeast and peptone were used as organic nitrogen sources the highest dry mass productivity was $17 \mathrm{~g} \mathrm{~L}^{-1}$, while at the same nitrogen and carbon concentrations of the growth medium, significantly higher dry biomass productivity was achieved with $16 \%$ and $32 \%(v / v)$ effluent concentration, $64.3 \pm 1.9$ and $64.2 \pm 2.1 \mathrm{~g} \mathrm{~L}^{-1}$, respectively, and $49.2 \pm 2.7 \mathrm{~g} \mathrm{~L}^{-1}$ with an effluent concentration of $48 \%(v / v)$.

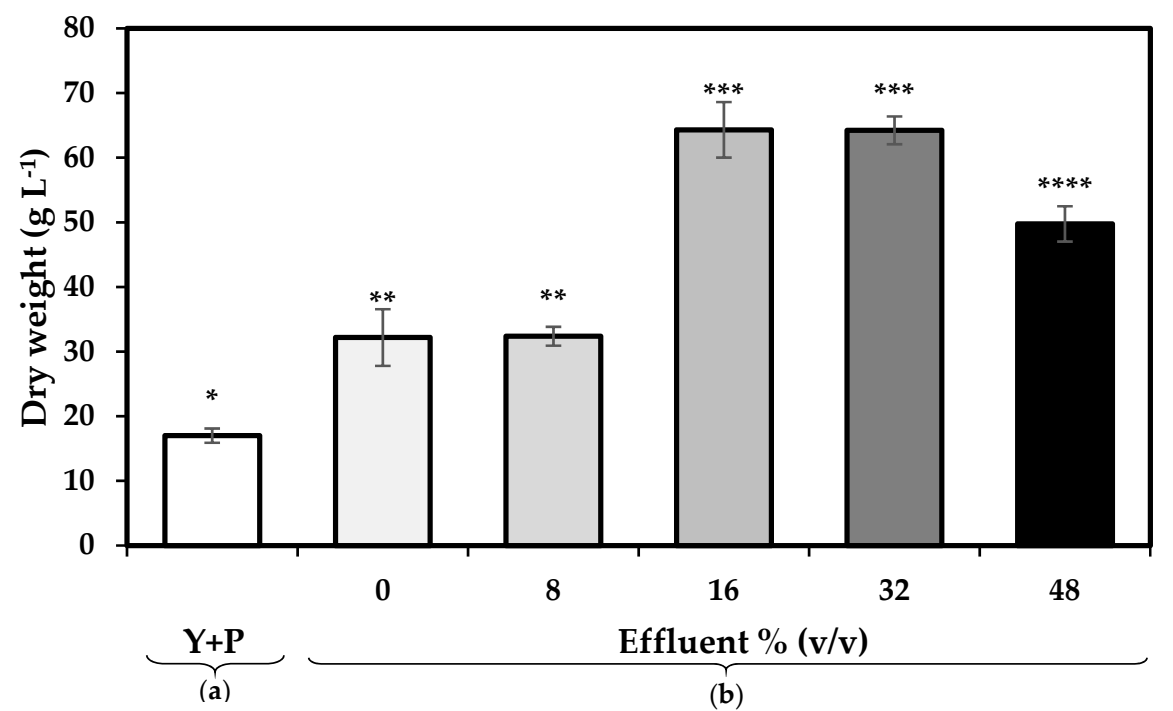

Figure 1. Comparison of biomass productivity of S. limacinum in growth media containing the same carbon (120 g L $\mathrm{g}^{-1}$ crude glycerol) concentration and (a) yeast and peptone $(\mathrm{Y}+\mathrm{P})$ and micronutrients or (b) varying volumes of effluent digestate (0-48\%) combined with $\mathrm{NH}_{4} \mathrm{Cl}$ that resulted in the same nitrogen $\left(3.3 \mathrm{~g} \mathrm{~L}^{-1}\right)$ concentrations, without additional micronutrients. Values are represented as mean \pm standard deviation of triplicates, whereas asterisks indicate statistical differences analyzed at a level of $p<0.05$.

\subsection{Total Lipids}

Lipid productivity of S. limacinum expressed in terms of total lipids content differed in respect to varying effluent concentrations (Figure 2). Lipid accumulation exhibited a proportional pattern with increasing concentrations of effluent, reaching the highest $(p<0.05)$ percentage $(\%)$ as proportion of dried algal biomass $17.1 \%$ and $17.3 \%$ at $32 \%$ and $48 \%(v / v)$ effluent concentrations, respectively (Table 1 ). Compared to yeast extract and peptone medium where the lipid yield was $10.2 \mathrm{~g} \mathrm{~L}^{-1}$, the fermentation medium with $32 \%$ and $48 \%$ of effluent without micronutrients had a lipid yield of 11.58 and $10.15 \mathrm{~g} \mathrm{~L}^{-1}$, respectively (Figure 2). 


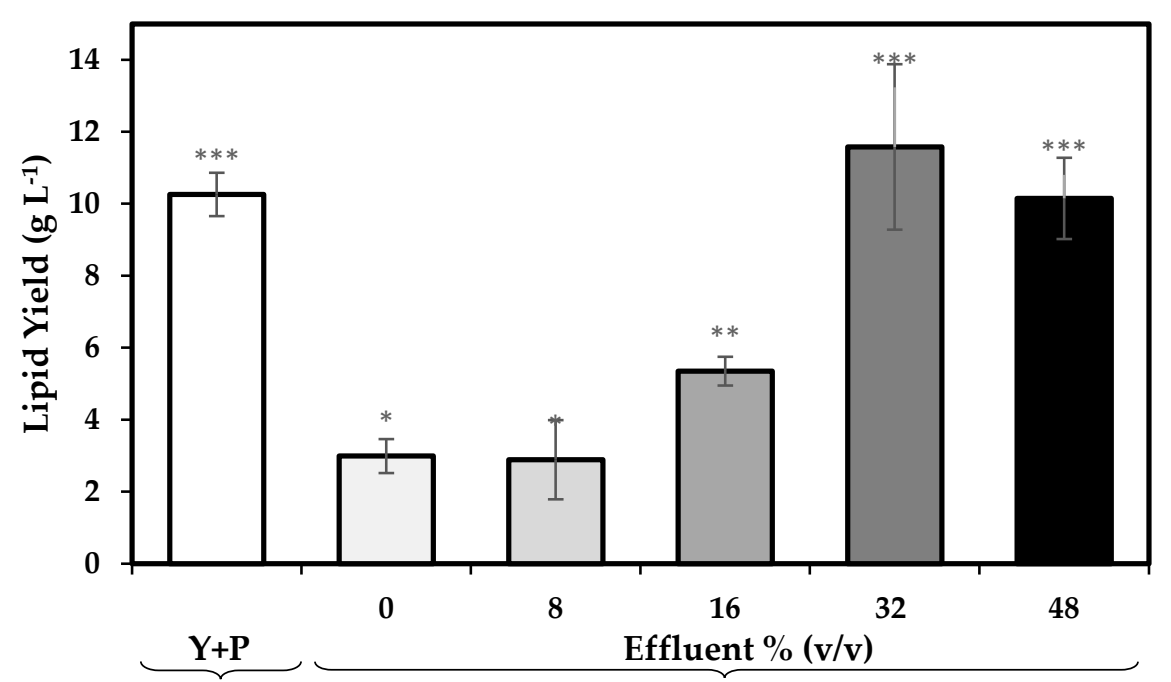

(a)

(b)

Figure 2. Comparison of lipid productivity of S. limacinum in growth media containing the same carbon (120 $\mathrm{g} \mathrm{L}^{-1}$ crude glycerol) concentration and (a) yeast and peptone $(\mathrm{Y}+\mathrm{P})$ and micronutrients or (b) varying volumes of effluent digestate $(0-48 \%)$ combined with $\mathrm{NH}_{4} \mathrm{Cl}$ that resulted in the same nitrogen $\left(3.3 \mathrm{~g} \mathrm{~L}^{-1}\right)$ concentrations, without additional micronutrients. Values are represented as mean \pm standard deviation of triplicates, whereas asterisks indicate statistical differences analyzed at a level of $p<0.05$

\subsection{Carbon Assimilation}

Carbon assimilation expressed in terms of total organic carbon content was highest $(p<0.05)$ at elevated effluent concentration, exhibiting approximately $40 \%$ reduction from the initial content, which was $37.5 \mathrm{~g} \mathrm{~L}^{-1}$ in all treatments (Figure 3).

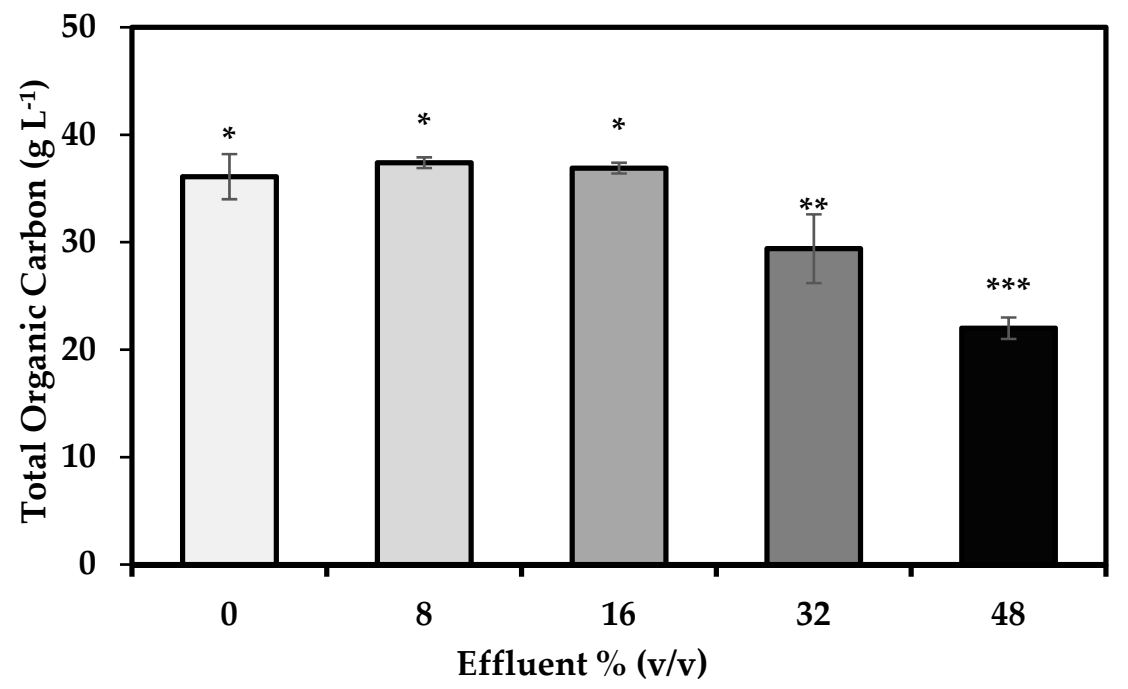

Figure 3. Effect of effluent digestate at varying concentrations (0-48\%) with the same carbon and nitrogen concentration of the medium without the addition of micronutrients on total organic carbon assimilation of S. limacinum. Values are represented as mean \pm standard deviation of triplicates, whereas asterisks indicate statistical differences analyzed at a level of $p<0.05$.

\subsection{Proximate Composition}

Increasing effluent concentrations in the culture media resulted in significantly lower crude protein content (Table 1). The highest total crude protein contents were achieved with the control 
culture and $8 \%$ effluent concentration with no significant differences between these two treatments. Elevated effluent concentrations resulted in significantly lower carbohydrate and gross energy contents. Ash content was significantly higher with increasing effluent concentrations; however, no differences were found between moderate and high concentrations.

Table 1. Proximate composition of dried algal biomass of S. limacinum grown on medium containing effluent digestate at varying concentrations $(0-48 \%)$ at the same carbon and nitrogen concentration without the addition of micronutrients.

\begin{tabular}{|c|c|c|c|c|c|c|}
\hline $\begin{array}{c}\text { Effluent } \\
\text { Concentration } \\
\%(v / v)\end{array}$ & $\begin{array}{l}\text { Crude } \\
\text { Protein } \\
(\%)\end{array}$ & $\begin{array}{c}\text { Crude Lipid } \\
(\%)\end{array}$ & $\begin{array}{c}\text { Crude } \\
\text { Carbohydrate } \\
(\%)\end{array}$ & $\begin{array}{l}\text { Moisture } \\
\text { Content } \\
(\%)\end{array}$ & $\begin{array}{c}\text { Ash } \\
\text { Content (\%) }\end{array}$ & $\begin{array}{c}\text { Gross } \\
\text { Energy } \\
\left(\mathrm{MJ} \mathrm{kg}^{-1}\right)\end{array}$ \\
\hline 0 & $30.8 \pm 0.9^{\mathrm{a} 1}$ & $8.9 \pm 1.4^{\mathrm{a}}$ & $54.3 \pm 3.1^{\mathrm{a}}$ & $0.37 \pm 0.03^{a}$ & $5.5 \pm 0.3^{a}$ & $18.5 \pm 0.1^{\mathrm{a}}$ \\
\hline 8 & $31.5 \pm 1.1^{\mathrm{a}}$ & $5.3 \pm 0.6^{\mathrm{a}}$ & $57.33 \pm 2.8^{a}$ & $0.27 \pm 0.01^{\mathrm{a}}$ & $5.6 \pm 0.2^{\mathrm{a}}$ & $18.7 \pm 2.8^{\mathrm{a}}$ \\
\hline 16 & $20.7 \pm 0.1^{b}$ & $7.8 \pm 0.8^{\mathrm{a}}$ & $39.89 \pm 1.1_{b}$ & $0.51 \pm 0.05^{\mathrm{a}}$ & $31.1 \pm 1.0^{\mathrm{b}}$ & $12.2 \pm 0.4^{b}$ \\
\hline 32 & $22.0 \pm 0.2^{b}$ & $17.1 \pm 3.4^{b}$ & $33.86 \pm 3.4^{b}$ & $0.44 \pm 0.08^{\mathrm{a}}$ & $26.6 \pm 2.0^{b}$ & $13.6 \pm 0.3^{b}$ \\
\hline 48 & $25.0 \pm 0.8^{b}$ & $17.3 \pm 3.5^{b}$ & $26.96 \pm 2.2^{c}$ & $0.34 \pm 0.04^{\mathrm{a}}$ & $30.4 \pm 8.1^{b}$ & $16.1 \pm 0.1^{\mathrm{c}}$ \\
\hline
\end{tabular}

${ }^{1}$ Values (percentages) are represented as the mean \pm standard deviation of triplicates, whereas letters $(\mathrm{a}, \mathrm{b}$ and $\mathrm{c})$ indicate statistical differences analyzed at a level of $p<0.05$.

\subsection{DHA Yield}

DHA yields of S. limacinum differed in respect to varying effluent concentrations (Figure 4). The concentrations of $32 \%$ and $48 \%$ exhibited the highest $(p<0.05)$ DHA yields at $504 \mathrm{mg} \mathrm{L}^{-1}$ and $761 \mathrm{mg} \mathrm{L}^{-1}$, respectively (Figure 4).

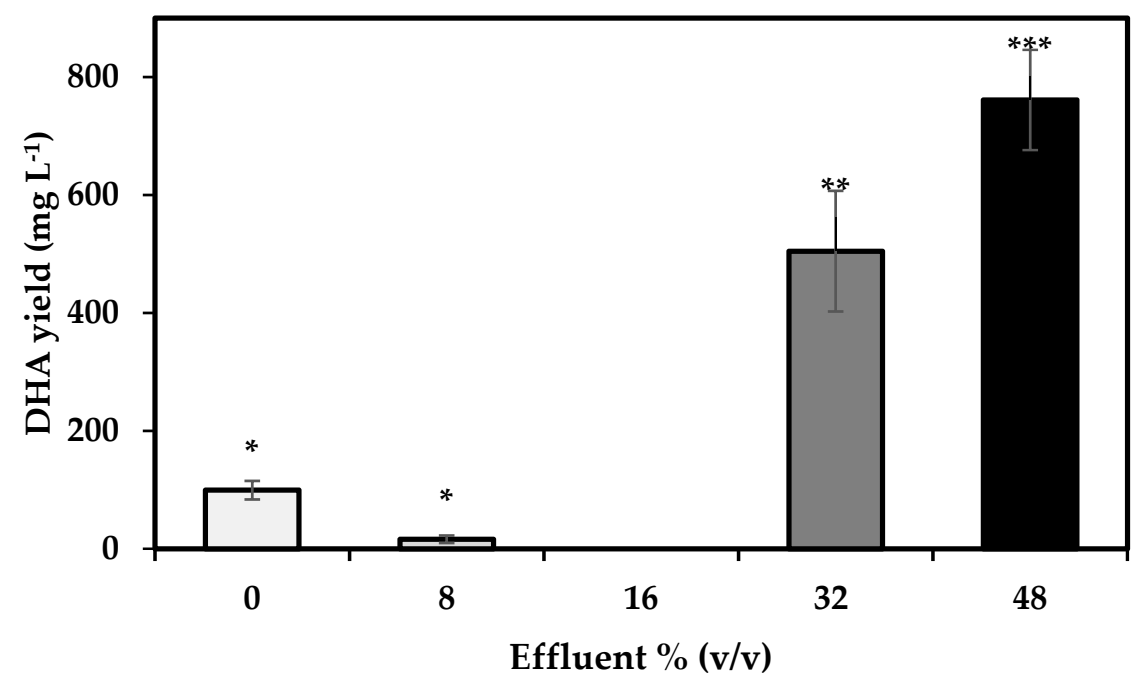

Figure 4. DHA yield of S. limacinum grown on medium containing effluent digestate at varying concentrations $(0-48 \%)$ with the same carbon and nitrogen concentration without the addition of micronutrients. Values are represented as mean \pm standard deviation of triplicates, whereas asterisks indicate statistical differences analyzed at a level of $p<0.05$.

\subsection{Fatty Acid Profile}

The fatty acid profile of S. limacinum is shown in Table 2, where palmitic acid (16:0) and stearic acid (18:0) were the major fatty acids in the total lipid content with DHA and myristic acid (14:0) exhibiting lower levers. The use of crude glycerol and effluent as culture media significantly changed the fatty acid profile of S. limacinum. In particular, the levels of 16:0 were significantly reduced and those of 18:0 were significantly increased in these treatments compared to the control one. In addition, there was a trend with elevated effluent concentrations resulting in increased levels of 16:0 and decreased levels of 18:0, but this was not significant $(p>0.05)$. With regard to the DHA content, moderate effluent 
concentrations ( $8 \%$ and $16 \%$ ) produced very limited amounts that were lower than those found in the control treatment. However, higher concentrations ( $32 \%$ and $48 \%$ ) resulted in considerable amounts of DHA that were similar or even slightly higher to those in the control. Furthermore, DPA was non-detectable in any substitution treatments.

Table 2. Fatty acid (percent of total fatty acids) composition of dried algal biomass of S. limacinum grown on medium containing effluent digestate at varying concentrations $(0-48 \%)$ with the same carbon and nitrogen concentration without the addition of micronutrients.

\begin{tabular}{|c|c|c|c|c|c|}
\hline $\begin{array}{c}\text { Effluent Concentration } \\
\qquad \%(v / v)\end{array}$ & $\begin{array}{c}\text { Myristic Acid } \\
14: 0 \\
(\%)\end{array}$ & $\begin{array}{c}\text { Palmitic Acid } \\
16: 0 \\
(\%)\end{array}$ & $\begin{array}{c}\text { Stearic Acid } \\
18: 0 \\
(\%)\end{array}$ & $\begin{array}{c}\text { DPA } \\
22: 5 n-6 \\
(\%)\end{array}$ & $\begin{array}{c}\text { DHA } \\
22: 6 n-3 \\
(\%)\end{array}$ \\
\hline 0 & $0.88 \pm 0.9^{a 1}$ & $54.70 \pm 17.8^{a}$ & $40.79 \pm 16.9^{a}$ & n.d & $3.33 \pm 1.7^{\mathrm{a}}$ \\
\hline 8 & $0.93 \pm 0.2^{a}$ & $17.72 \pm 1.3^{b}$ & $80.79 \pm 1.5^{b}$ & n.d & $0.56 \pm 0.1^{\mathrm{a}}$ \\
\hline 16 & $0.44 \pm 0.4^{\mathrm{a}}$ & $19.38 \pm 1.2^{b}$ & $80.17 \pm 1.0^{b}$ & n.d & n.d \\
\hline 32 & $0.73 \pm 0.7^{a}$ & $20.10 \pm 0.8^{b}$ & $74.83 \pm 3.8^{b}$ & n.d & $4.34 \pm 0.5^{\mathrm{a}}$ \\
\hline 48 & n.d & $21.19 \pm 0.8^{b}$ & $71.26 \pm 1.4^{b}$ & n.d & $7.5 \pm 1.2^{b}$ \\
\hline
\end{tabular}

${ }^{1}$ Values (percentages) are represented as the mean \pm standard deviation of triplicates, whereas letters (a and b) indicate statistical differences analyzed at a level of $p<0.05$, n.d.: $<0.01 \%$ of total fatty acids.

\section{Discussion}

4.1. Effect of the Replacement of Organic Nitrogen Sources with Pre-Treated Effluent Enriched with Inorganic Nitrogen on Biomass and Lipid Productivity

Nitrogen serves as an essential component for eukaryotic microalgae cells for the synthesis of important cellular constitutes (peptides, enzymes, ATP and DNA) in order to sustain growth and development [60]. Yeast extract is an organic nitrogen source widely used in microbial fermentation due to its essential content in amino acids, vitamins and trace elements [61]. It is the most expensive ingredient in thraustochytrids culture media, considering that in order to reach a biomass productivity of $60 \mathrm{~g} \mathrm{~L}^{-1}$ and DHA content of $20 \mathrm{~g} \mathrm{~L}^{-1}$, the addition of $4 \% w / v$ yeast extract is necessary [36,49]. Furthermore, nitrogen sources, which favor optimal growth and development, are species-specific [35]. Therefore, several nutrient sources, organic or none, have been proposed in order to reduce production cost and optimize nutrient media for optimal biomass productivity and DHA yield of S. limacinum. According to Yokochi, et al. [62], the highest biomass productivity of $15 \mathrm{~g} \mathrm{~L}^{-1}$ was achieved when the culture media was supplied with yeast extract and corn steep liquor in batch cultures with regard the organic nitrogen sources. In the same study, when inorganic nutrient sources were used, the biomass increased approximately $40 \%$ with ammonium sulfate, urea and ammonium acetate. However, ammonium acetate was more favorable for lipid accumulation and DHA yield. Silkina, et al. [63] utilized pre-treated effluent as an alternative nutrient source for heterotrophic cultivation of S. limacinum with pure glycerol. Even though nutrient removal of ammonia and phosphates was successful, which was the main focus of the study, DHA content was not measured, and their low biomass productivity $\left(1.3 \mathrm{~g} \mathrm{~L}^{-1}\right)$ constitutes a limiting factor for industrial production standards. In this current study, organic nutrients sources (yeast extract, glycerol and peptone) were successfully substituted with low cost nitrogen sources $\left(\mathrm{NH}_{4} \mathrm{Cl}\right)$, crude glycerol and effluent digestate rich in trace elements, achieving a biomass productivity $49.2 \pm 2.7 \mathrm{~g} \mathrm{~L}^{-1}$, three times higher compared to the treatment with the organic nitrogen sources and comparable to earlier mentioned studies, while the total lipid production was equal to that obtained with organic sources. This is in accordance with Sun et al. [40], where organic nitrogen inhibited cell growth because it was utilized for the synthesis of cell components rather than cell reproduction [64], which could explain the significant lower biomass recorded in the treatment with yeast extract and peptone. In the same study, when monosodium glutamate was used as the inorganic nitrogen source, lipid accumulation was enhanced. One of the essential amino acids contained in abundance in yeast extract is glutamic acid (glutamate) [65]. It has 
been reported that nutrient media containing monosodium glutamate can inhibit cell growth and increase lipid accumulation, a fact that would justify the similar total lipid content between inorganic and organic nitrogen sources.

The enrichment of the effluent with inorganic nitrogen source can be further limited, if the effluent is nitrated by air stirring before sterilization, as the direct sterilization of the effluent leads to a loss of inorganic nitrogen (almost 55\%, data not shown). This is due to the conversion of ammonium nitrogen to ammonia, a reaction influenced with increasing temperature levels.

\subsection{Effect of the Replacement of Micronoutrients with Pre-Treated Effluent}

Micronutrients are an important ingredient in microbial culture media influencing several biochemical processes. Although research on the effect of micronutrients on thraustochytrids is limited, it has been reported that under combined $\mathrm{Fe}, \mathrm{Cu}, \mathrm{Zn}$ and $\mathrm{Mn}$ limiting conditions, biomass productivity is impeded in several Schizochytrium and fungi species [66-68]. Consequently, the increase in biomass and lipid productivity with increasing concentrations of effluent in our study could be attributed to the increasing concentrations of trace elements, since nitrogen, phosphorous and potassium content was almost identical with negligible differences among the treatments. However, the decline in biomass at high effluent concentrations $(48 \% v / v)$ could be due to high concentrations of copper $\left(5.6 \mathrm{mg} \mathrm{L}^{-1}\right)$ and zinc $\left(12 \mathrm{mg} \mathrm{L}^{-1}\right)$, since it has been reported that concentrations of copper above $0.5 \mathrm{mg} \mathrm{L}^{-1}$ can induce growth inhibition in several Schizochytrium sp. [69]. Furthermore, the increased lipid content at moderate and high effluent concentrations was probably induced by the increasing concentration of Fe. To the best of our knowledge, no research has been conducted in Schizochytrium sp. and Fe limited conditions; however, several studies on oleaginous fungi indicate a positive relationship between Fe and lipogenesis $[70,71]$ due to its role in the synthesis of citrate, which serves as substrate for acetyl-CoA a precursor for fatty acid synthesis $[64,68]$.

\subsection{Effect of Varying Effluent Concentrations on Proximate Composition of S. Limacinum Dried Biomass}

The elevated concentrations of the effluent resulted in reduced protein contents. In fact, the protein content was negatively correlated (Pearson correlation $0.988, p<0.01$ ) to the biomass productivity, indicating that the assimilated nitrogen in the elevated concentrations of effluent was more directed towards growth rather than deposition, with $16 \%$ and $32 \%$ levels, resulting in the highest growth and the lowest protein contents [72]. Furthermore, the increasing lipid content followed by reduced crude carbohydrate and total organic carbon content indicates that the influx of crude glycerol is utilized for lipogenesis. Gross energy values recorded at $16 \%$ and $32 \%$ effluent concentrations were the lowest, reflecting a utilization trend towards biomass production as revealed by the higher yield in these treatments. On the other hand, at low effluent concentrations ( $0 \%$ and $8 \%)$ S. limacinum exhibited the highest gross energy values that arise primarily from an increased accumulation of carbohydrates and to a lesser extent of proteins. The ash content was significantly higher at moderate and elevated effluent concentrations compared to earlier studies, which reported values ranging from 2.1-15.3\% [73]. This can be probably attributed due to the inorganic salts $\mathrm{NH}_{4} \mathrm{Cl}$ and $\mathrm{KH}_{2} \mathrm{PO}_{3}$ used in order to regulate nitrogen and phosphorus concentration in the culture media. This is in accordance with previous research, where the addition of ammonium sulfate led to an increased accumulation of ash [40]. Moreover, most microalgae species have the ability to uptake more phosphorus than necessary for cell growth and development when it becomes available. This ability is defined as luxury uptake where the surplus phosphorus is stored in the form of inorganic polyphosphates [74].

\subsection{Carbon Assimilation by S. limacinum on Media with Crude Glycerol and Varying Effluent Concentrations}

The fact that a $40 \%$ reduction of crude glycerol content was achieved at elevated effluent concentrations suggests that heterotrophic cultivation of S. limacinum can successfully remediate waste products from the biofuel industry. However, the crude glycerol consumption observed in this study is lower compared to earlier studies, where crude glycerol was assimilated up to $70 \%$ [9]. 
This could be attributed to the higher crude glycerine concentration used in the batch fermentation of the present study that, in turn, induced substrate inhibition, which is often the case at high glycerol concentrations $[36,75]$.

\subsection{DHA Yield and Fatty Acid Profile of S. limacinum}

DHA productivity is closely related to low dissolved oxygen levels ranging from $10 \%$ to $30 \%$ [76,77]. However, high oxygen levels are favorable for biomass productivity [9] ranging from $40-50 \%$. This is in line with the results of the present study, since compared to earlier studies [33,36,62], the biomass productivity observed was substantially high $\left(49.2 \pm 2.7 \mathrm{~g} \mathrm{~L}^{-1}\right)$ followed by low DHA levels $\left(760 \pm 85 \mathrm{mg} \mathrm{L}^{-1}\right)$. With regards to the maximum DHA yield, which was achieved at elevated concentrations, this could be attributed to increased Fe concentration, since fatty acid desaturases are iron contained enzymes responsible for sequential addition of double bonds to saturated fatty acids in order to produce DHA [72]. Furthermore, it has been suggested that iron concentration is closely related to PUFA synthesis in fungi [70].

The fatty acid profile of $S$. limacinum at varying concentrations of effluent, contained primarily 18:0 (71-80\% TFA), 16:0 (17-21\% TFA) with DHA constituting only a small fraction (3-7\% TFA). Under ideal conditions and optimized culture media, according to the literature the main fatty acids of Schizochytrium sp. are 16:0, DPA and DHA [78]. According to recent evidence, fatty acid synthesis in thraustochytrids involves two independently operating pathways. The first pathway requires molecular oxygen and produces short chain fatty acids 16:0 that can further elongate to 18:0. The second pathway, being oxygen independent and responsible for the production of DHA and DPA is the polyketide synthase (PKS) pathway [79]. A possible explanation for the elevated fraction of 16:0 and 18:0 fatty acids found in our study could be due to high oxygen levels, which upregulated the FAS pathway at the expense of DHA production through the anaerobic PKS pathways. This is in line with other research where high dissolved oxygen levels increased the fraction of short chain fatty acids [80], indicating a strong dependence on the abiotic environment besides optimal nutrient concentrations.

Although lipid productivity and DHA yield was very low compared to previous studies, the utilization of crude glycerol and effluent digestates as alternative nutrient sources can be successfully implemented in thraustochytrids fermentation media under optimized culture conditions. Furthermore, the medium composition suggested in the present study can also serve as an alternative economic solution for the seed culture in order to substitute conventional media, which primarily contain glucose, yeast extract and trace elements, since in this production, stage lipid productivity is irrelevant.

\section{Conclusions}

In the present study, it was evidenced that crude glycerol and effluent from anaerobic digestate, which are waste products derived from the biofuel industry, can serve as alternative nutrient source inputs in S. limacinum cultivation. The optimal effluent concentration in order to maximize DHA production was $48 \% v / v$, yielding $49.7 \mathrm{~g} \mathrm{~L}^{-1}$ biomass and $0.8 \mathrm{~g} \mathrm{~L}^{-1}$ DHA with intracellular lipids containing primarily 18:0 saturated fatty acids. The use of $S$. limacinum can be an effective tool for the waste stream processing of the biofuel industry, since this species can efficiently utilize crude glycerol as a carbon source for growth and development. Moreover, it was shown that yeast extract, trace elements and artificial sea salts can be effectively replaced by inorganic fertilizers and effluent for the heterotrophic cultivation of S. limacinum. The importance of trace elements in the culture of S. limacinum is highlighted by this study, while future research is needed to enlighten their effects on biomass productivity and DHA yield of the species. In order for the implementation of digested effluent to be applicable in the fermentation of S. limacinum at an industrial scale, and simultaneously, to produce a product that could be used in aquafeeds for fish oil replacement, it is necessary to improve the DHA yields through optimization of the cultivation conditions. 
The above process of the use of biofuel industrial waste streams as resource input in microalgae cultivation, which in turn can be used for the production of aquaculture feeds with high nutritional value, is in line with the circular economy concept.

Author Contributions: Conceptualization, N.K. and I.T.K.; Data curation, S.B.; Funding acquisition, N.K.; Investigation, S.B. and D.A.; Methodology, S.B. and D.A.; Project administration, N.K.; Supervision, N.K.; Writing-original draft, S.B.; Writing-review and editing, N.K., D.A. and I.T.K. All authors have read and agreed to the published version of the manuscript.

Funding: This research has been co-financed by the European Union and Greek national funds through the Operational Program Competitiveness, Entrepreneurship and Innovation, under the call RESEARCH-CREATE-INNOVATE (project code: T1EDK-01580).

Conflicts of Interest: The authors declare no conflict of interest.

\section{References}

1. Yuan, Z.; Bi, J.; Moriguichi, Y. The circular economy: A new development strategy in China. J. Ind. Ecol. 2006, 10, 4-8. [CrossRef]

2. Sariatli, F. Linear Economy versus Circular Economy: A comparative and analyzer study for Optimization of Economy for Sustainability. Visegr. J. Bioecon. Sustain. Dev. 2017, 6, 31-34. [CrossRef]

3. Geissdoerfer, M.; Savaget, P.; Bocken, N.M.; Hultink, E.J. The Circular Economy-A new sustainability paradigm? J. Clean. Prod. 2017, 143, 757-768. [CrossRef]

4. Shu, Q.; Gao, J.; Nawaz, Z.; Liao, Y.; Wang, D.; Wang, J. Synthesis of biodiesel from waste vegetable oil with large amounts of free fatty acids using a carbon-based solid acid catalyst. Appl. Energy 2010, 87, 2589-2596. [CrossRef]

5. Taufiq-Yap, Y.; Farabi, M.A.; Syazwani, O.; Ibrahim, M.L.; Marliza, T. Sustainable Production of Bioenergy. In Innovations in Sustainable Energy and Cleaner Environment; Springer: Berlin/Heidelberg, Germany, 2020; pp. 541-561.

6. Declerck, F.; Indjehagopian, J.-P.; Lantz, F. Dynamics of biofuel prices on the European market: Impact of the EU environmental policy on the resources markets. SSRN 2020. SSRN 3542376. [CrossRef]

7. Pyle, D.J.; Garcia, R.A.; Wen, Z. Producing docosahexaenoic acid (DHA)-rich algae from biodiesel-derived crude glycerol: Effects of impurities on DHA production and algal biomass composition. J. Agric. Food Chem. 2008, 56, 3933-3939. [CrossRef]

8. Thompson, J.C.; He, B.B. Characterization of crude glycerol from biodiesel production from multiple feedstocks. Appl. Eng. Agric. 2006, 22, 261-265. [CrossRef]

9. Chi, Z.; Pyle, D.; Wen, Z.; Frear, C.; Chen, S. A laboratory study of producing docosahexaenoic acid from biodiesel-waste glycerol by microalgal fermentation. Process Biochem. 2007, 42, 1537-1545. [CrossRef]

10. McNutt, J.; Yang, J. Utilization of the residual glycerol from biodiesel production for renewable energy generation. Renew. Sustain. Energy Rev. 2017, 71, 63-76.

11. Skoulou, V.K.; Zabaniotou, A.A. Co-gasification of crude glycerol with lignocellulosic biomass for enhanced syngas production. J. Anal. Appl. Pyrolysis 2013, 99, 110-116. [CrossRef]

12. Manara, P.; Zabaniotou, A. Co-pyrolysis of biodiesel-derived glycerol with Greek lignite: A laboratory study. J. Anal. Appl. Pyrolysis 2013, 100, 166-172. [CrossRef]

13. Xiu, S.; Shahbazi, A.; Wallace, C.W.; Wang, L.; Cheng, D. Enhanced bio-oil production from swine manure co-liquefaction with crude glycerol. Energy Convers. Manag. 2011, 52, 1004-1009. [CrossRef]

14. Kumar, R.P.; Bharathiraja, B.; Kataki, R.; Moholkar, V. Biomass Valorization to Bioenergy; Springer: Berlin/Heidelberg, Germany, 2019.

15. Guo, X.M.; Trably, E.; Latrille, E.; Carrere, H.; Steyer, J.-P. Hydrogen production from agricultural waste by dark fermentation: A review. Int. J. Hydrogen Energy 2010, 35, 10660-10673. [CrossRef]

16. Uggetti, E.; Passos, F.; Solé, M.; Garfí, M.; Ferrer, I. Recent achievements in the production of biogas from microalgae. Waste Biomass Valorization 2017, 8, 129-139. [CrossRef]

17. Möller, K.; Müller, T. Effects of anaerobic digestion on digestate nutrient availability and crop growth: A review. Eng. Life Sci. 2012, 12, 242-257. [CrossRef]

18. Lin, H.; Gan, J.; Rajendran, A.; Reis, C.E.R.; Hu, B. Phosphorus removal and recovery from digestate after biogas production. In Biofuels-Status and Perspective; IntechOpen: London, UK, 2015. 
19. Sogn, T.A.; Dragicevic, I.; Linjordet, R.; Krogstad, T.; Eijsink, V.G.; Eich-Greatorex, S. Recycling of biogas digestates in plant production: NPK fertilizer value and risk of leaching. Int. J. Recycl. Org. Waste Agric. 2018, 7, 49-58. [CrossRef]

20. Zhu, L.; Yan, C.; Li, Z. Microalgal cultivation with biogas slurry for biofuel production. Bioresour. Technol. 2016, 220, 629-636. [CrossRef]

21. Kobayashi, N.; Noel, E.A.; Barnes, A.; Watson, A.; Rosenberg, J.N.; Erickson, G.; Oyler, G.A. Characterization of three Chlorella sorokiniana strains in anaerobic digested effluent from cattle manure. Bioresour. Technol. 2013, 150, 377-386. [CrossRef]

22. Singh, M.; Reynolds, D.L.; Das, K.C. Microalgal system for treatment of effluent from poultry litter anaerobic digestion. Bioresour. Technol. 2011, 102, 10841-10848. [CrossRef]

23. Ji, F.; Liu, Y.; Hao, R.; Li, G.; Zhou, Y.; Dong, R. Biomass production and nutrients removal by a new microalgae strain Desmodesmus sp. in anaerobic digestion wastewater. Bioresour. Technol. 2014, 161, $200-207$. [CrossRef]

24. Nematian, T.; Salehi, Z.; Shakeri, A. Conversion of bio-oil extracted from Chlorella vulgaris micro algae to biodiesel via modified superparamagnetic nano-biocatalyst. Renew. Energy 2020, 146, 1796-1804. [CrossRef]

25. Sun, Y.; Cheng, J. Hydrolysis of lignocellulosic materials for ethanol production: A review. Bioresour. Technol. 2002, 83, 1-11. [CrossRef]

26. Dhargalkar, V.; Verlecar, X. Southern Ocean seaweeds: A resource for exploration in food and drugs. Aquaculture 2009, 287, 229-242. [CrossRef]

27. Humphrey, A. Chlorophyll as a color and functional ingredient. J. Food Sci. 2004, 69, C422-C425. [CrossRef]

28. Kumar, M.; Sharma, M.K.; Kumar, A. Spirulina fusiformis: A food supplement against mercury induced hepatic toxicity. J. Health Sci. 2005, 51, 424-430. [CrossRef]

29. Stiles, W.A.; Styles, D.; Chapman, S.P.; Esteves, S.; Bywater, A.; Melville, L.; Silkina, A.; Lupatsch, I.; Grünewald, C.F.; Lovitt, R. Using microalgae in the circular economy to valorise anaerobic digestate: Challenges and opportunities. Bioresour. Technol. 2018, 267, 732-742. [CrossRef]

30. Marchan, L.F.; Chang, K.J.L.; Nichols, P.D.; Mitchell, W.J.; Polglase, J.L.; Gutierrez, T. Taxonomy, ecology and biotechnological applications of thraustochytrids: A review. Biotechnol. Adv. 2018, 36, 26-46. [CrossRef]

31. Leyland, B.; Leu, S.; Boussiba, S. Are thraustochytrids algae? Fungal Biol. 2017, 121, 835-840. [CrossRef]

32. Cavalier-Smith, T.; Allsopp, M.; Chao, E. Thraustochytrids are chromists, not fungi: 18S rRNA signatures of Heterokonta. Philos. Trans. R. Soc. London. Ser. B Biol. Sci. 1994, 346, 387-397.

33. Zhu, L.; Zhang, X.; Ren, X.; Zhu, Q. Effects of culture conditions on growth and docosahexaenoic acid production from Schizochytrium limacinum. J. Ocean Univ. China 2008, 7, 83-88. [CrossRef]

34. Chen, C.-Y.; Lee, M.-H.; Leong, Y.K.; Chang, J.-S.; Lee, D.-J. Biodiesel production from heterotrophic oleaginous microalga Thraustochytrium sp. BM2 with enhanced lipid accumulation using crude glycerol as alternative carbon source. Bioresour. Technol. 2020, 306, 123113. [CrossRef] [PubMed]

35. Chen, G.; Fan, K.-W.; Lu, F.-P.; Li, Q.; Aki, T.; Chen, F.; Jiang, Y. Optimization of nitrogen source for enhanced production of squalene from thraustochytrid Aurantiochytrium sp. New Biotechnol. 2010, 27, 382-389. [CrossRef] [PubMed]

36. Huang, T.Y.; Lu, W.C.; Chu, I.M. A fermentation strategy for producing docosahexaenoic acid in Aurantiochytrium limacinum SR21 and increasing C22: 6 proportions in total fatty acid. Bioresour. Technol. 2012, 123, 8-14. [CrossRef] [PubMed]

37. Allen, K.M.; Habte-Tsion, H.-M.; Thompson, K.R.; Filer, K.; Tidwell, J.H.; Kumar, V. Freshwater microalgae (Schizochytrium sp.) as a substitute to fish oil for shrimp feed. Sci. Rep. 2019, 9, 1-10. [CrossRef] [PubMed]

38. Ju, J.-H.; Ko, D.-J.; Heo, S.-Y.; Lee, J.-J.; Kim, Y.-M.; Lee, B.-S.; Kim, M.-S.; Kim, C.-H.; Seo, J.-W.; Oh, B.-R. Regulation of lipid accumulation using nitrogen for microalgae lipid production in Schizochytrium sp. ABC101. Renew. Energy 2020, 153, 580-587. [CrossRef]

39. Katerina, K.; Berge, G.M.; Turid, M.; Aleksei, K.; Grete, B.; Trine, Y.; Mats, C.; John, S.; Bente, R. Microalgal Schizochytrium limacinum Biomass Improves Growth and Filet Quality When Used Long-Term as a Replacement for Fish Oil, in Modern Salmon Diets. Front. Mar. Sci. 2020, 7, 57. [CrossRef]

40. Sun, L.; Ren, L.; Zhuang, X.; Ji, X.; Yan, J.; Huang, H. Differential effects of nutrient limitations on biochemical constituents and docosahexaenoic acid production of Schizochytrium sp. Bioresour. Technol. 2014, 159, 199-206. [CrossRef] 
41. Ratledge, C.; Cohen, Z. Microbial and algal oils: Do they have a future for biodiesel or as commodity oils? Lipid Technol. 2008, 20, 155-160. [CrossRef]

42. Wang, S.-K.; Wang, X.; Tian, Y.-T.; Cui, Y.-H. Nutrient recovery from tofu whey wastewater for the economical production of docosahexaenoic acid by Schizochytrium sp. S31. Sci. Total Environ. 2020, 710, 136448. [CrossRef]

43. Song, X.; Zang, X.; Zhang, X. Production of high docosahexaenoic acid by Schizochytrium sp. using low-cost raw materials from food industry. J. Oleo Sci. 2015. [CrossRef]

44. Thyagarajan, T.; Puri, M.; Vongsvivut, J.; Barrow, C.J. Evaluation of bread crumbs as a potential carbon source for the growth of Thraustochytrid species for oil and omega-3 production. Nutrients 2014, 6, 2104-2114. [CrossRef] [PubMed]

45. Yamasaki, T.; Aki, T.; Shinozaki, M.; Taguchi, M.; Kawamoto, S.; Ono, K. Utilization of Shochu distillery wastewater for production of polyunsaturated fatty acids and xanthophylls using thraustochytrid. J. Biosci. Bioeng. 2006, 102, 323-327. [CrossRef] [PubMed]

46. Unagul, P.; Assantachai, C.; Phadungruengluij, S.; Suphantharika, M.; Tanticharoen, M.; Verduyn, C. Coconut water as a medium additive for the production of docosahexaenoic acid (C22: $6 \mathrm{n} 3$ ) by Schizochytrium mangrovei Sk-02. Bioresour. Technol. 2007, 98, 281-287. [CrossRef] [PubMed]

47. Liang, Y.; Sarkany, N.; Cui, Y.; Yesuf, J.; Trushenski, J.; Blackburn, J.W. Use of sweet sorghum juice for lipid production by Schizochytrium limacinum SR21. Bioresour. Technol. 2010, 101, 3623-3627. [CrossRef] [PubMed]

48. Chi, Z.; Liu, Y.; Frear, C.; Chen, S. Study of a two-stage growth of DHA-producing marine algae Schizochytrium limacinum SR21 with shifting dissolved oxygen level. Appl. Microbiol. Biotechnol. 2009, 81, 1141-1148. [CrossRef]

49. Humhal, T.; Kastanek, P.; Jezkova, Z.; Cadkova, A.; Kohoutkova, J.; Branyik, T. Use of saline waste water from demineralization of cheese whey for cultivation of Schizochytrium limacinum PA-968 and Japonochytrium marinum AN-4. Bioprocess Biosyst. Eng. 2017, 40, 395-402. [CrossRef]

50. Xu, J.; Zhu, Y.; Li, H.; Chen, L.; Chen, W.; Cui, M.; Han, L.; Hou, W.; Li, D. Alanine mother liquor as a nitrogen source for docosahexaenoic acid production by Schizochytrium sp. B4D1. Electron. J. Biotechnol. 2018, 35, 10-17. [CrossRef]

51. Turchini, G.M.; Trushenski, J.T.; Glencross, B.D. Thoughts for the future of aquaculture nutrition: Realigning perspectives to reflect contemporary issues related to judicious use of marine resources in aquafeeds. N. Am. J. Aquac. 2019, 81, 13-39. [CrossRef]

52. Naylor, R.L.; Goldburg, R.J.; Primavera, J.H.; Kautsky, N.; Beveridge, M.C.; Clay, J.; Folke, C.; Lubchenco, J.; Mooney, H.; Troell, M. Effect of aquaculture on world fish supplies. Nature 2000, 405, 1017-1024. [CrossRef]

53. Hemaiswarya, S.; Raja, R.; Kumar, R.R.; Ganesan, V.; Anbazhagan, C. Microalgae: A sustainable feed source for aquaculture. World J. Microbiol. Biotechnol. 2011, 27, 1737-1746. [CrossRef]

54. Kamlangdee, N.; Fan, K. Polyunsaturated fatty acids production by Schizochytrium sp. isolated from mangrove. Songklanakarin J. Sci. Tech. 2003, 25, 643-650.

55. Becker, E. Micro-algae as a source of protein. Biotechnol. Adv. 2007, 25, 207-210. [CrossRef] [PubMed]

56. Olsen, S.; Sommers, L. Phosphorus. In Methods of Soil Analysis. Part 2. Chemical and Microbiological Properties, 2nd ed.; Page, A.L., Ed.; Agron. Monogr. 9. ASA and SSSA: Madison, WI, USA, 1982; pp. 403-427.

57. Chen, W.; Zhou, P.-p.; Zhang, M.; Zhu, Y.-m.; Wang, X.-p.; Luo, X.-a.; Bao, Z.-d.; Yu, L.-j. Transcriptome analysis reveals that up-regulation of the fatty acid synthase gene promotes the accumulation of docosahexaenoic acid in Schizochytrium sp. S056 when glycerol is used. Algal Res. 2016, 15, 83-92. [CrossRef]

58. Folch, J.; Lees, M.; Stanley, G.S. A simple method for the isolation and purification of total lipides from animal tissues. J. Biol. Chem. 1957, 226, 497-509.

59. Christie, W.; Han, X. Lipid Analysis: Isolation. Separation, Identification and Structural Analysis of Lipids; Barnes: Bridgwater, UK, 2003.

60. Barsanti, L.; Gualtieri, P. Algae: Anatomy, Biochemistry, and Biotechnology; CRC press: Boca Raton, FL, USA, 2014.

61. Kasprow, R.P.; Lange, A.J.; Kirwan, D.J. Correlation of fermentation yield with yeast extract composition as characterized by near-infrared spectroscopy. Biotechnol. Prog. 1998, 14, 318-325. [CrossRef]

62. Yokochi, T.; Honda, D.; Higashihara, T.; Nakahara, T. Optimization of docosahexaenoic acid production by Schizochytrium limacinum SR21. Appl. Microbiol. Biotechnol. 1998, 49, 72-76. [CrossRef] 
63. Silkina, A.; Zacharof, M.-P.; Hery, G.; Nouvel, T.; Lovitt, R.W. Formulation and utilisation of spent anaerobic digestate fluids for the growth and product formation of single cell algal cultures in heterotrophic and autotrophic conditions. Bioresour. Technol. 2017, 244, 1445-1455. [CrossRef]

64. Ratledge, C. Fatty acid biosynthesis in microorganisms being used for single cell oil production. Biochimie 2004, 86, 807-815. [CrossRef]

65. Jewell, D.; Lin, H.; Goshaw, D. High Nutrient Yeast. U.S. Patent 0326484 A1, 10 November 2016.

66. Nagano, N.; Taoka, Y.; Honda, D.; Hayashi, M. Effect of trace elements on growth of marine eukaryotes, tharaustochytrids. J. Biosci. Bioeng. 2013, 116, 337-339. [CrossRef]

67. Philpott, C.C. Iron uptake in fungi: A system for every source. Biochim. Biophys. Acta Mol. Cell Res. 2006, 1763, 636-645. [CrossRef]

68. Chaisawang, M.; Verduyn, C.; Chauvatcharin, S.; Suphantharika, M. Metabolic networks and bioenergetics of Aurantiochytrium sp. B-072 during storage lipid formation. Braz. J. Microbiol. 2012, 43, 1192-1205. [CrossRef] [PubMed]

69. Lin, Y.-C.; Leaño, E.M.; Pang, K.-L. Effects of Cu (II) and Zn (II) on growth and cell morphology of thraustochytrids isolated from fallen mangrove leaves in Taiwan. Bot. Mar. 2010, 53, 581-586. [CrossRef]

70. Dedyukhina, E.; Chistyakova, T.; Vainshtein, M. Biosynthesis of arachidonic acid by micromycetes. Appl. Biochem. Microbiol. 2011, 47, 109-117. [CrossRef]

71. Pádrová, K.; Čejková, A.; Cajthaml, T.; Kolouchová, I.; Vítová, M.; Sigler, K.; Řezanka, T. Enhancing the lipid productivity of yeasts with trace concentrations of iron nanoparticles. Folia Microbiol. 2016, 61, 329-335. [CrossRef]

72. Monroig, Ó.; Tocher, D.R.; Navarro, J.C. Biosynthesis of polyunsaturated fatty acids in marine invertebrates: Recent advances in molecular mechanisms. Mar. Drugs 2013, 11, 3998-4018. [CrossRef]

73. Liang, Y.; Sarkany, N.; Cui, Y.; Blackburn, J.W. Batch stage study of lipid production from crude glycerol derived from yellow grease or animal fats through microalgal fermentation. Bioresour. Technol. 2010, 101, 6745-6750. [CrossRef]

74. Solovchenko, A.E.; Ismagulova, T.T.; Lukyanov, A.A.; Vasilieva, S.G.; Konyukhov, I.V.; Pogosyan, S.I.; Lobakova, E.S.; Gorelova, O.A. Luxury phosphorus uptake in microalgae. J. Appl. Phycol. 2019, 31, 2755-2770. [CrossRef]

75. Jun, S.-A.; Moon, C.; Kang, C.-H.; Kong, S.W.; Sang, B.-I.; Um, Y. Microbial fed-batch production of 1, 3-propanediol using raw glycerol with suspended and immobilized Klebsiella pneumoniae. Appl. Biochem. Biotechnol. 2010, 161, 491-501. [CrossRef]

76. Ganuza, E.; Izquierdo, M. Lipid accumulation in Schizochytrium G13/2S produced in continuous culture. Appl. Microbiol. Biotechnol. 2007, 76, 985-990. [CrossRef]

77. Chang, G.; Luo, Z.; Gu, S.; Wu, Q.; Chang, M.; Wang, X. Fatty acid shifts and metabolic activity changes of Schizochytrium sp. S31 cultured on glycerol. Bioresour. Technol. 2013, 142, 255-260. [CrossRef]

78. Ren, L.-J.; Huang, H.; Xiao, A.-H.; Lian, M.; Jin, L.-J.; Ji, X.-J. Enhanced docosahexaenoic acid production by reinforcing acetyl-CoA and NADPH supply in Schizochytrium sp. HX-308. Bioprocess Biosyst. Eng. 2009, 32, 837. [CrossRef] [PubMed]

79. Morabito, C.; Bournaud, C.; Maës, C.; Schuler, M.; Cigliano, R.A.; Dellero, Y.; Maréchal, E.; Amato, A.; Rébeillé, F. The lipid metabolism in thraustochytrids. Prog. Lipid Res. 2019, 76, 101007. [CrossRef] [PubMed]

80. Chang, K.J.L.; Nichols, C.M.; Blackburn, S.I.; Dunstan, G.A.; Koutoulis, A.; Nichols, P.D. Comparison of thraustochytrids Aurantiochytrium sp., Schizochytrium sp., Thraustochytrium sp., and Ulkenia sp. for production of biodiesel, long-chain omega-3 oils, and exopolysaccharide. Mar. Biotechnol. 2014, 16, 396-411. [CrossRef] [PubMed]

(C) 2020 by the authors. Licensee MDPI, Basel, Switzerland. This article is an open access article distributed under the terms and conditions of the Creative Commons Attribution (CC BY) license (http://creativecommons.org/licenses/by/4.0/). 